\title{
Energy Auditing in Electrical Sciences Block
}

\author{
A.Lavanya, J.Divya Navamani, E.Siddharth Mannadiar, Harshvardhan Katare,Ria Rastogi
}

\begin{abstract}
The energy consumption has seen a vast increment because of which the use of non-sustainable sources has increased drastically. Due to this steep increase, the need of energy auditing and conservation has also increased. Growing demand for energy directly increases emission of effluents, causing environmental catastrophe. To tackle this problem a collaboration between energy audit and conservation conservation of energy is required. Energy audit is a procedural approach which is used for a clear description of the energy flow and energy management. This collective data helps in calculating the efficiency and minimizing operational cost. The aim of this project is to carry out the energy audit for the Electrical Sciences Block (ESB) of SRM INSTITUTE OF SCIENCE AND TECHNOLOGY. The main purpose of the following literature is to give a clear picture of the energy details of the ESB block.
\end{abstract}

Keywords-conservation, pvsyst, standalone PV system, energy auditing.

\section{INTRODUCTION}

The need of sustainable sources of energy has seen a steep increase in commercial applications. The use of solar energy as an alternative source of conventional systems is one such application. This paper pitches an idea of implementation of energy auditing and the need for conservation of energy. Energy audit helps in reducing the dependency on conventional sources of energy and can be used to switch to alternate source of energy with pre-defined calculations [1].PVSYST is a software package which offers wide range of facilities of designing, sizing, data analyzing of complete PV System to engineers, architects and researchers. It can be used for various PV systems for variety of uses as configured by user settings menu. It offers a user- friendly approach with a guide to develop a project. For making maximum use of the simulation, real time data are to be taken and followed up with subsequent iterations.[2]

\section{PVGIS estimates of solar electricity generation}

Solar radiation for the location potheri SRMIST data is collected from PVGIS-CMSAF .For the system considered the following values are tabulated. Electricity production daily average in $\mathrm{kWh}$, Electricity production on a monthly average in $\mathrm{kWh}$,Sum of global irradiation received in $\mathrm{kWh} / \mathrm{m} 2$ is also recorded.Table 1 depicts the solar radiation data for potheri SRMIST location. Fig. 1 shows the PV estimate and fig. 2 shows the irradiation estimate for the site

Revised Version Manuscript Received on 10, September 2019.

A.Lavanya, Department of Electrical and Electronics Engineering, SRMIST, Kattankulathur, Chennai, Tamilnadu, India.

J.Divya Navamani, Department of Electrical and Electronics Engineering, SRMIST, Kattankulathur, Chennai, Tamilnadu, India.

E.Siddharth Mannadiar, Department of Electrical and Electronics Engineering, SRMIST, Kattankulathur, Chennai, Tamilnadu, India.

Harshvardhan Katare, Department of Electrical and Electronics Engineering, SRMIST, Kattankulathur, Chennai, Tamilnadu, India.

Ria Rastogi, Department of Electrical and Electronics Engineering, SRMIST, Kattankulathur, Chennai, Tamilnadu, India selected.

Table 1 : Solar radiation data for Potheri location

Stationary system: inclination $=0^{\circ}$, orientation $=0^{\circ}$

\begin{tabular}{|c|c|c|c|c|}
\hline Month & $A v g_{d}$ & $A v g_{m}$ & $S_{d}$ & $S_{m}$ \\
\hline Jan & 3.95 & 123 & 5.48 & 170 \\
\hline Feb & 4.54 & 127 & 6.36 & 178 \\
\hline Mar & 4.96 & 154 & 7.08 & 220 \\
\hline Apr & 4.86 & 146 & 7.00 & 210 \\
\hline May & 4.47 & 138 & 6.49 & 201 \\
\hline Jun & 4.07 & 122 & 5.87 & 176 \\
\hline Jul & 3.81 & 118 & 5.46 & 169 \\
\hline Aug & 3.95 & 122 & 5.63 & 174 \\
\hline Sep & 4.03 & 121 & 5.73 & 172 \\
\hline Oct & 3.48 & 108 & 4.89 & 152 \\
\hline Nov & 3.22 & 96.6 & 4.48 & 135 \\
\hline Dec & 3.35 & 104 & 4.62 & 143 \\
\hline
\end{tabular}

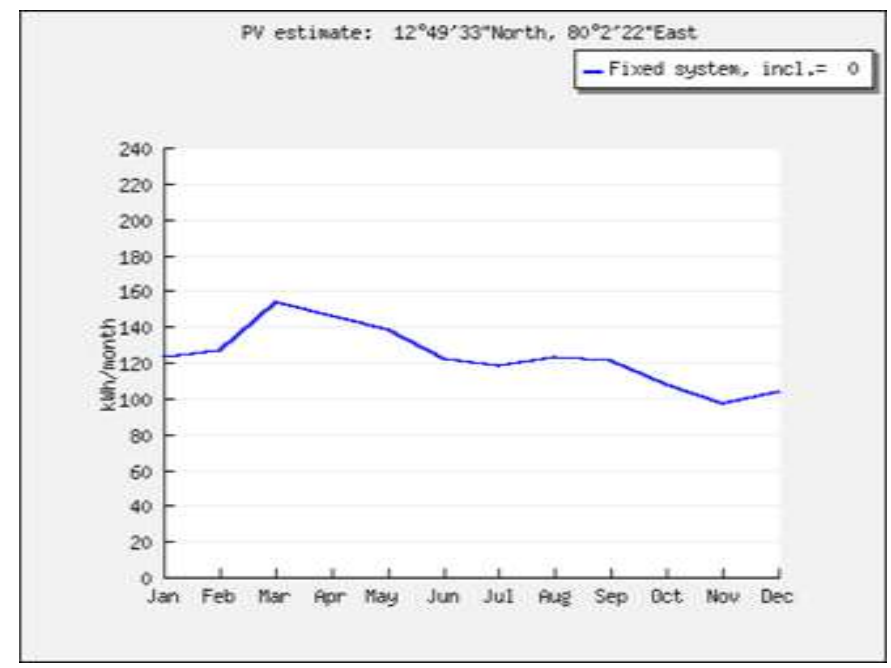

Fig. 1 PV estimate 


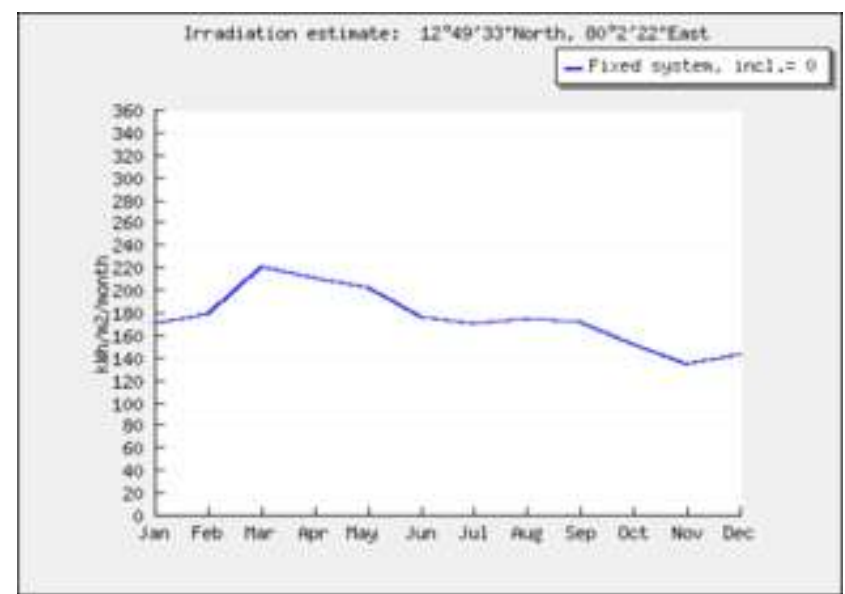

Fig. 2 Irradiation estimate

The features of pvsyst are listed below:

1. "Metronome inside"- Provides the location on earth with the help of google map tool. Provides monthly meteo values for any site with the help of interpolating possibilities of meteonorm 6.1.

2. New Project Management and simulation process-

Offers new project management dashboard along with direct access to all parameters, simulation and results in a single dialog.

3. Improved shading calculations

4. Detailed electrical shading losses

5. PV Modules

6. Inverters

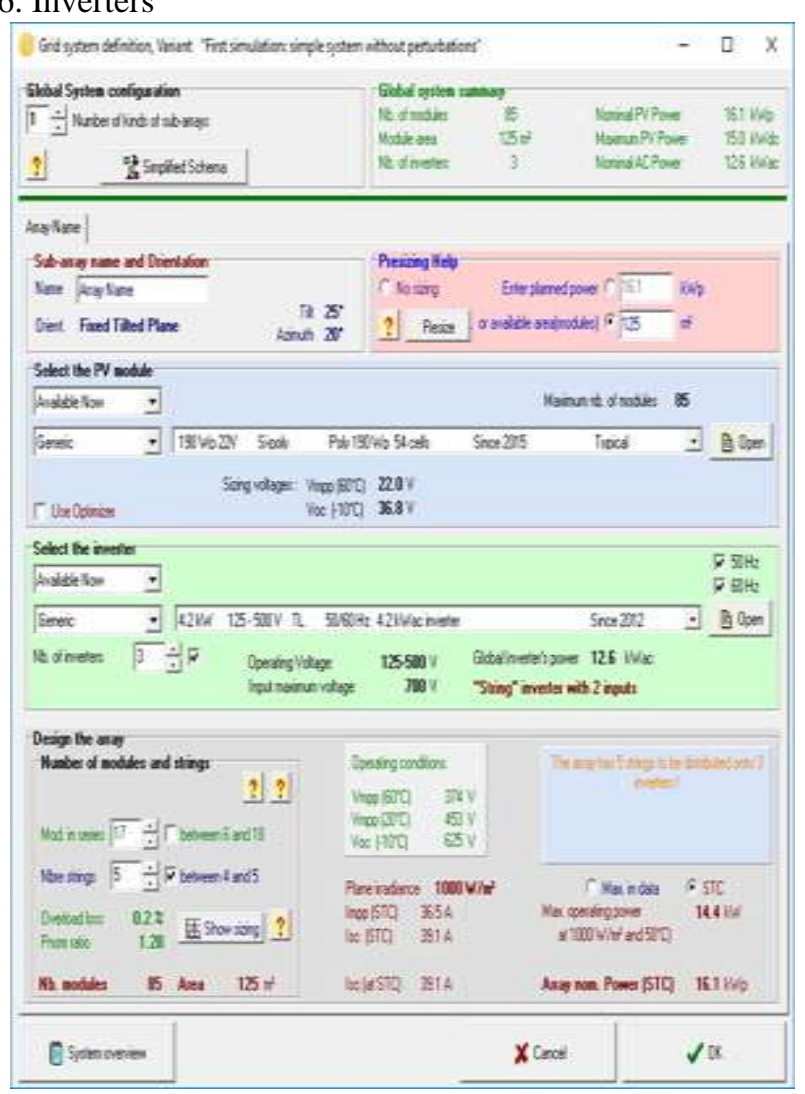

Fig. 3 Input Parameters of PVSYST

\section{SITE SELECTION}

Factors affecting site selection:

- Area should be less than 150 metre square.

- It should get direct sunlight for longer duration.

- Should not be situated near tall trees and building to not get shadows.

- It should get direct sunlight from 9 am to $3 \mathrm{pm}$.

\section{FRAMEWORK FOR DESIGNING STANDALONE SYSTEM.}

A literature survey of the entire building was tabulated according to the types of the loads present. Most common loads were fluorescent lamps, Ceiling Fans, LED bulbs etc. Also, the standard losses exhibited by the PV systems and the auxiliary system were taken into account. Fig. 3 shows the line graphs of the load distribution in the staff rooms and classrooms. The majority of the loads present in the staffrooms as well as classrooms are fluorescent lamps, ceiling fans, Air conditioners. All the ratings and the outputs should be in compliance with the rules and regulations. It helps in improving the system efficiency[3].The following are the losses taken into account before designing the system.

-HEAT LOSSES-The analysis simulates with a series of gradual stages determining the behaviour of the system under losses due to heat generated at each and every individual stage, this helps in operating of instantaneous temperature operating in PVSYST. The thermal balance includes heat loss factor.

-WIRING LOSSES-the wiring loss includes losses due to ohmic resistance of the wire and helps in determining the instantaneous changes in these losses. As wiring loss behave as square of the current, a default global wiring loss fraction of $1.5 \%$ by respect to STC is used.

-MODULE QUALITY LOSS-It is mainly based on the reflection seen in matching the module with real time application that is by respect to the manufacturer's specifications.

-MISMATCH LOSS-It gives the details about the losses related to the I/V characteristics of the PV array or module. This parameter acts as a constant loss in simulation process. These losses can be nullified when the when the modules are sorted according to their real performance.

-SOILING LOSS-This effect is more prominent in hot and humid climatic locations and also near the railway services.

-IAM LOSS-The incidence effect determines the decrease in the irradiation reaching the surface of a cell to that of the irradiation at a normal incidence. Let us assume that an isotropic diffusion has taken place and now the IAM factor is calculated by integrating the selected spaces and thereby including the low incidence areas.

\section{USES OF PVSYST}

PVSYST is the most powerful tool used for designing Photovoltaic system. The following are the advantages in using this software tool:

- It produces various simulation results that helps us in comparing them with the the real time needs.

- The energy auditor can define various specific attributes and can view various outputs like thermal characteristics, PV output quality, mismatch and also statistical attributes of the actual site where the installation of PV has to take place. 
- The loss diagram is an pictorial representation of the real time losses occurring in the system which help us in determining the modifications to be done in the design.

- The pvsyst consists of a tool specifically designed for a brief financial analysis which gives the approximate investment to be done for the design.

- The results of the pvsyst can be graphed or tabulated which helps in maintenance and systematic organisation of the output data.

III. LOAD DISTRIBUTION
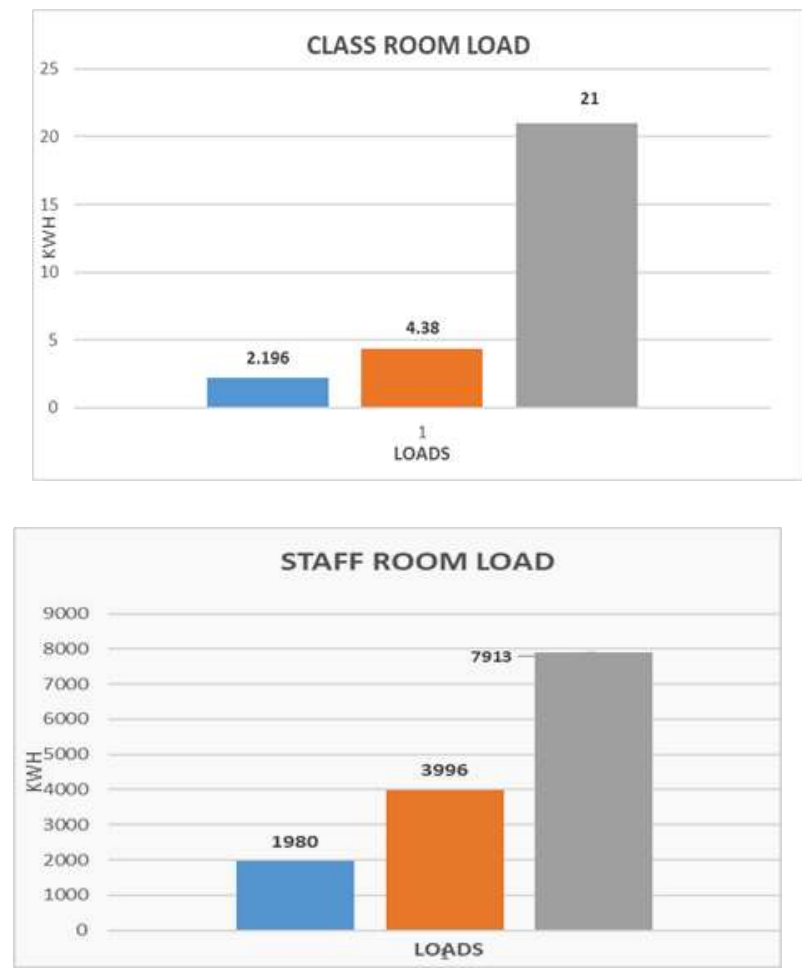

Fig.4 Class Room and Staff Room Loads

The above graphs shown in fig 4 depict the power consumption of lights, fan, air conditioners which are used in the class rooms and laboratories.Standalone System Parameters

The geographical site chosen for the standalone system is Madras. The chosen place has latitude of $13.07 \mathrm{~N}$ and Longitude of $80.25 \mathrm{E}$. The system to be used is a standalone system with batteries. The main objective is to provide $147 \mathrm{kwh} /$ day. The PV system has the following specifications as shown in fig 5. Successful Energy management requires the establishment of a system to collect analyze and report on the Energy costs and consumption [4].

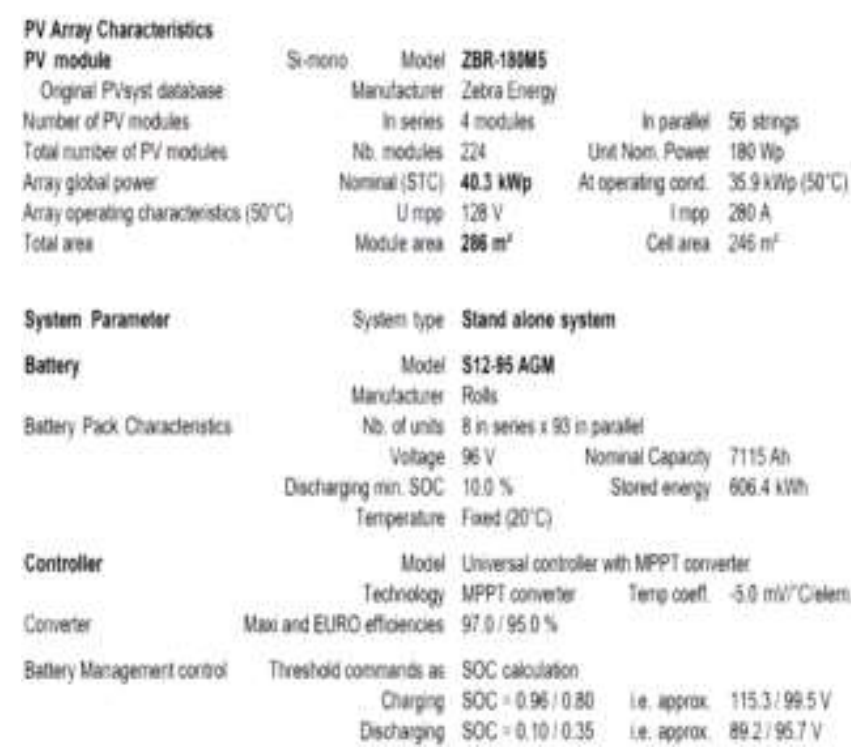

Fig.5 Standalone Grid Parameters

\section{STANDALONE SYSTEM USER NEEDS}

Modern and advanced energy efficient appliances are highly needed to substitute the conventional ones.[5] The system needs to provide enough electricity to power 138 fluorescent lamps rated $36 \mathrm{~W}$ each, 138 tube lights rated $36 \mathrm{~W}$ each and 138 ceiling fans rated $60 \mathrm{~W}$ each. The running time for the loads is given as follows. 8 hours for ceiling fans, 5 hours for fluorescent lamps and 6 hours LED lamps. The above running time is defined on the basis of the average daily consumption.

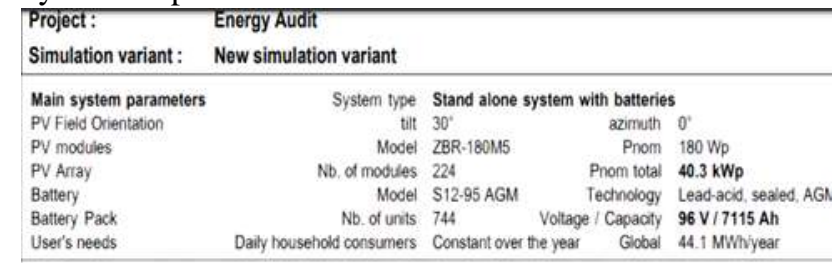

Daily household consumers, Constant over the year, average $=121 \mathrm{kWh} / \mathrm{day}$

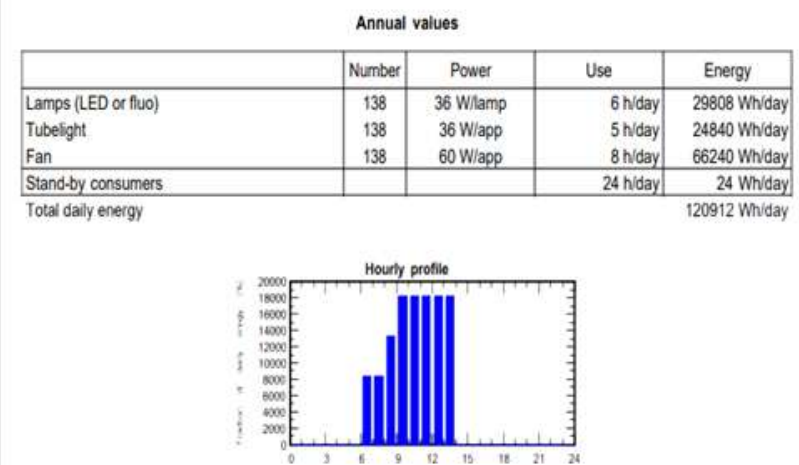

Fig.6 Hourly Load Distribution

The graphs in fig 6 basically show the hourly consumption in a single day and the total power consumed by each of the equipment. 


\section{SIMULATION RESULTS}

The simulation result in fig 7 shows all the necessary data

Main system parameters
PV Fieid Orientation
PV modules
PV Array
Battery
Battery Pack
User's needs

Main simulation results

System Production

\section{Loss of Load \\ Battery ageing (State of Wear)}

\section{Investment \\ Yearly cost \\ Energy cost}

System type

\section{tilt}

Model

Nb. of modules

Model

$\mathrm{Nb}$. of units

Daily household consumers to be provided for the assembly of the standalone grid. The simulation results along with the power generation graphs

for each month is shown below.

Stand alone system with batteries

$$
30^{*}
$$

ZBR-180M5

224

S12-95 AGM

744

azimuth

Pnom $180 \mathrm{Wp}$

Prom total $\mathbf{4 0 . 3} \mathrm{kWp}$

Technology Lead-acid, sealed. AGM

Voltage / Capacity 96 V / 7115 Ah
Global 44.1 MWhylyear

Available Energy

Used Energy

Performance Ratio PR

Time Fraction

Cycles sow

Battery lifetime

Global ind. taxes

Annuities (Loan $5.0 \%, 20$ years)

$\begin{array}{lrl}\mathbf{5 8 0 1 5} \mathrm{kWh} / \text { year } & \text { Specific prod. } & 1439 \mathrm{kWh} / \mathrm{kWp} / \text { year } \\ 44133 \mathrm{kWh} / \text { year Excess (unused) } & 11381 \mathrm{kWh} / \text { year } \\ 57.69 \% & \text { Solar Fraction SF } & 100.00 \% \\ 0.0 \% & \text { Missing Energy } & 0 \mathrm{kWh} / \text { year } \\ 95.8 \% & \text { Static SOW } & 90.0 \% \\ 10.0 \text { years Cost of stored energy } & 19.2 \text { INR/kWh } \\ 3839900 \mathrm{INR} & \text { Specific } & 95.2 \text { INR/Wp } \\ 308124 \mathrm{INR} / \mathrm{yr} & \text { Running Costs } & 300000 \mathrm{INR} / \mathrm{yr} \\ \mathbf{1 3 . 8} \text { INR/kWh } & & \end{array}$

Normalased productions coer installed $\mathrm{kWpl:}$ Nominal power $40.3 \mathrm{kWp}$

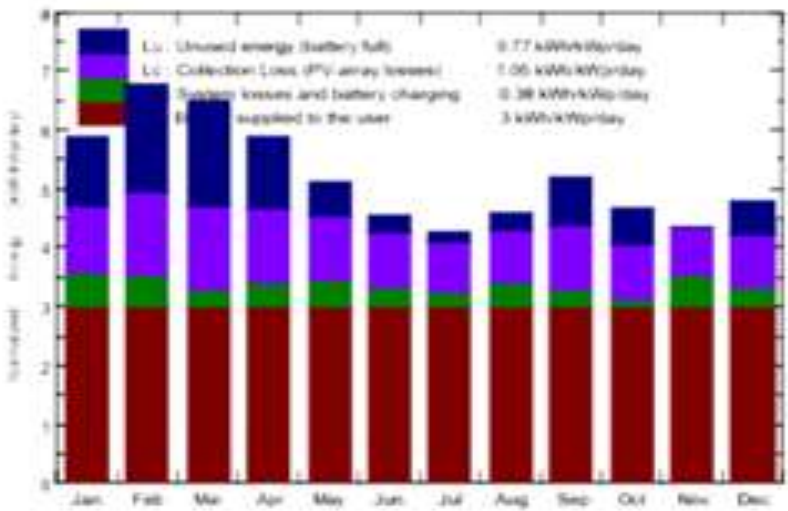

Perfoemance Ratio PR and Solar Fraction sf

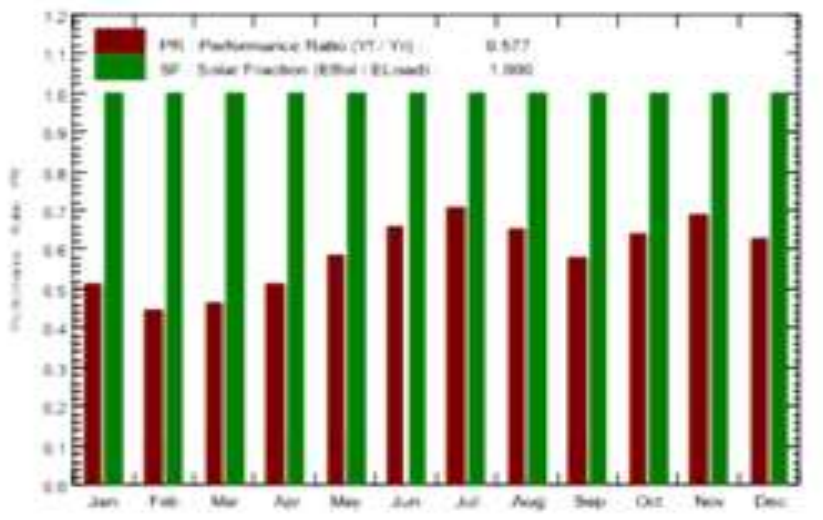

Fig.7-Simulation Results

The total number of PV modules required is 224 .The Standalone grid shall consist of Lead Acid Batteries with 744 units.The total Voltage of the grid will be 96v/7115ah.The Excess Energy that is produced can be exported to the grid.

The data calculated has been considered on the basis of average monthly solar irradiation. The energy audits need to be performed every 4 years for continuous monitoring of consumption [6]. The following table in fig 8 gives the brief data analysis of the energy generation,which can be further classified as unsused,used,missing energy as well as the parameters considered with respect to the requirements of the user.
New simulation variant

Balances and main results

\begin{tabular}{|c|c|c|c|c|c|c|c|c|c|}
\hline & & $\begin{array}{l}\text { GlobHor } \\
\text { kWhm? }\end{array}$ & $\begin{array}{l}\text { Globeff } \\
\text { Whimm? }\end{array}$ & $\begin{array}{l}\text { E_Avali } \\
\text { WWh }\end{array}$ & $\begin{array}{c}\text { EUnused } \\
\text { kWh }\end{array}$ & $\begin{array}{l}\text { E.Miss } \\
\text { WWh }\end{array}$ & $\begin{array}{l}\text { E. User } \\
\text { Wh }\end{array}$ & $\begin{array}{c}\text { E_Lood } \\
\mathrm{kWh}\end{array}$ & Solfrac \\
\hline Janusry & & 149.9 & 177.7 & 5606 & 621 & 0.0 & 4518 & 4518 & 1000 \\
\hline February & & 1649 & 1850 & 5768 & 1410 & 0.0 & 4081 & 4081 & 1000 \\
\hline March & & 1985 & 1952 & 6049 & 1279 & 00 & 4518 & 4518 & 1000 \\
\hline April & & 1940 & 1706 & 5267 & 765 & 0.0 & 4373 & 4373 & 1.000 \\
\hline May & & 1925 & 151.9 & 4709 & 0 & 00 & 4518 & 4518 & 1000 \\
\hline June & & 169.0 & 130.7 & 4123 & 0 & 0.0 & 4973 & 4373 & 1.000 \\
\hline July & & 160.8 & 126.3 & 4000 & 0 & 529.3 & 3989 & 4518 & 0.893 \\
\hline August & & 161.7 & 137.1 & 4328 & 0 & 171.3 & 4347 & 4518 & 0.962 \\
\hline Septembe & & 160.7 & 150.8 & 4601 & 1 & 0.0 & 4373 & 4373 & 1.000 \\
\hline Octobet & & 197.7 & 1407 & 4399 & 0 & 0.0 & 4518 & 4516 & 1000 \\
\hline Novembe & & 115.5 & 1267 & 4028 & 0 & 568.1 & 3805 & 4373 & 0.870 \\
\hline Decembe & & 124.1 & 144.1 & 4579 & 0 & 00 & 4518 & 4518 & 1.000 \\
\hline Year & & 1927.4 & 1836.8 & 57569 & 4076 & 1268.7 & 61931 & 63198 & 0.976 \\
\hline \multirow[t]{4}{*}{ Legonds: } & Gloothor & \multicolumn{4}{|c|}{ Hocizontal global inadlation } & E.Mus & \multicolumn{3}{|c|}{ Missing energy } \\
\hline & GlobEH & \multirow{2}{*}{\multicolumn{4}{|c|}{ EHoctio Global corr. for laMl and shadings }} & E_User & \multicolumn{3}{|c|}{ Energy suppliod to the user } \\
\hline & E_Aval & & & & & E_Losd & \multirow{2}{*}{\multicolumn{3}{|c|}{$\begin{array}{l}\text { Energy nood of the user Load } \\
\text { Solar fraction iEUsed Elosd) }\end{array}$}} \\
\hline & EUnused & \multicolumn{4}{|c|}{ Unused enorgy (batery full) } & Solfrac & & & \\
\hline
\end{tabular}

Fig.8 Irradiation Distribution

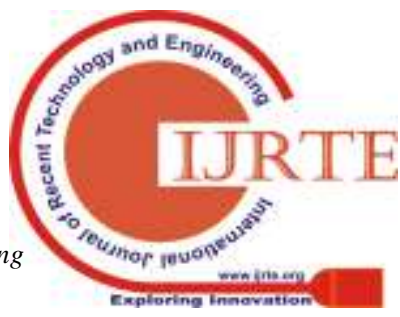




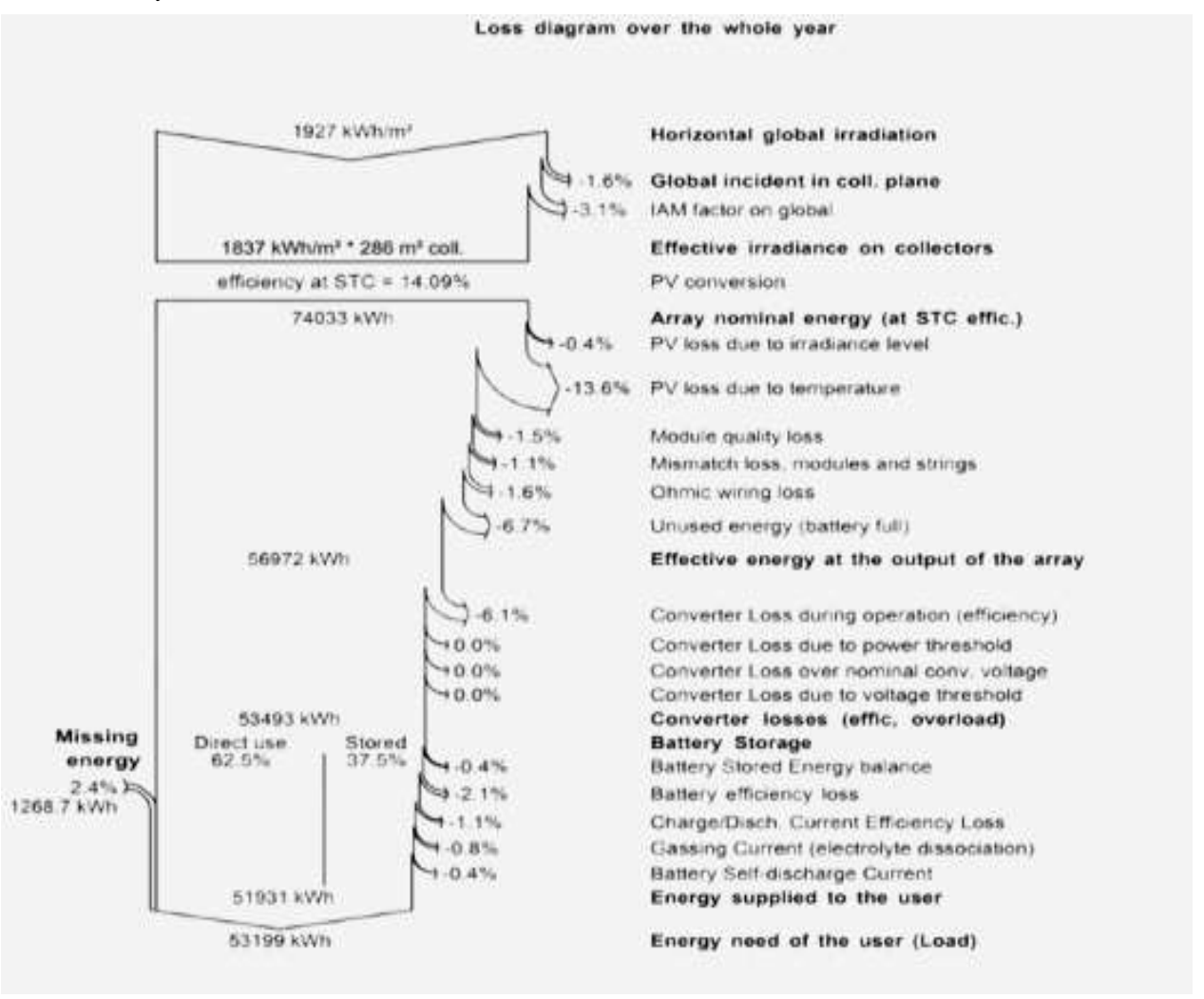

Fig.9 Loss Diagram

The losses in the standalone system can be briefly pictured in the loss diagram in fig 9 .The loss diagram is a yealy pictorial data describing all kinds of losses which might be due to the PV,Batery,Power Converters Over a span of one whole year.The paramerters important for consideration can be classfied into two systems,main systems and standalone systems.The main system consists of paramerters related to PV cells and their orientation, the orientation is of PV celss is tilted ant an angle of 30 degrees while the battery pack used is a lead acid Battery consisting a battery pack of 744 units. The vltage capacity being 96 V/7115 Ah.The users needs has been considered and losses has been calculated by pv syst.Considerabe losses has been observed due to high temperature of the $\mathrm{pv}$ which is abut $-13.67 \%$ The converter loss during operation is about $-6.1 \%$ while the battery storage gives on an average about-5\% loss due to efficiency,gassing current,self discharge current and its own loss . Considering the following parameters, Energy Auditing is very successful in improving energy efficiency and cost effectiveness and also reduce the energy gap.[7]

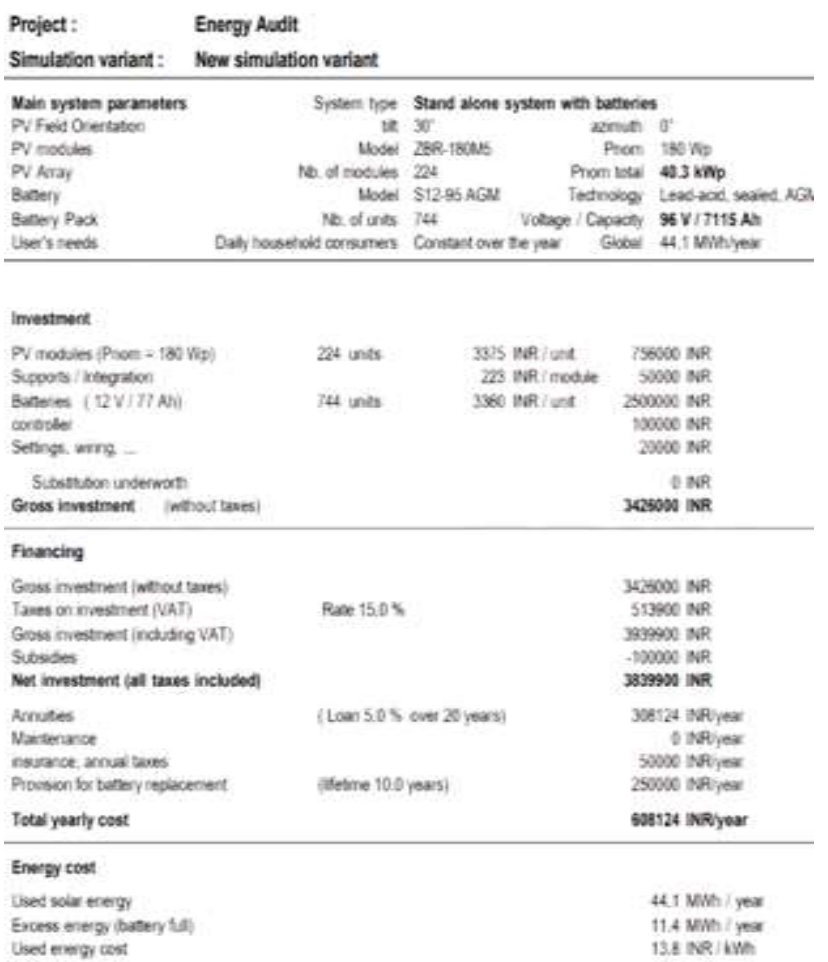

Fig.10 Economic Evaluation

As observed, the following method helps in reducing the electricity bills. A steep decline of $15 \%$ is observed[8]. The above table in fig 10 includes cost breakup for the installation of a solar panel. The initial investment for the instalation is Rs 3426000 without taxes and by including the taxes and excluding the subsidies the net investment for its installation 
is Rs 3839900. By taking the maintainence of the panel, insurance and the annual taxes into consideration the total yearly cost would be Rs 608124. The solar energy used would be $44.1 \mathrm{MWh} /$ year and the excess energy consumed is 11.4 MWh/year. The total used energy cost is $13.8 \mathrm{INR} / \mathrm{kWh}$.

\section{V.CONCLUSION}

This paper infers an energy auditing study that is performed for the electrical sciences blocks of SRM institute of Science and Technology. This study demonstrates that the present electrical energy usage of the same can be reduced by switching to a standalone grid thereby reducing the dependency on the grid. In addition, the surplus power generated can be exported to the power deficient areas or can be net metered and incentives can be availed.

\section{REFERENCE}

1. Malik Sameeullah, Jitendra Kumar, Kanhaiya Lal, Jagdish Chander, "Energy Audit: A Case Study of Hostel Building", International Journal of Research in Management Science \& Technology, vol. 2, no. 2, August 2014.

2. Cem Keskin, Umut Asan, Gulgun Kayakutlu, "Value Stream Maps for Industrial Energy Efficiency", Proceedings of PICMET '12: Technology Management for Emerging Technologies, 2012.

3. B.Kipnis Andrew, "Audit cultures: neoliberal governmentality socialist legacy or technologies of governing?", American Ethnologist, vol. 35, no. 2, pp. 275-289, 2008.

4. A. Thumann and W. J. Younger, "Handbook of Energy Audits (7th Ed. ), " Fairmont Press, 1-12, 2008.

5. PVsyst software. CUEPE, University of Geneva. www.pvsyst.com

6. European Commission Science Hub. (2013). Photovoltaic geographical information system (PVGIS). [Online]. Available: https://ec.europa.eu/ $\mathrm{jrc} / \mathrm{en} / \mathrm{scientific}-$ tool/pvgis

7. ISO 50001:2011 Energy management systems Requirements with guidance for use, 2011, [online].

8. S. R. Bhawarkar and S. Y. Kamdi, "Electrical Energy Audit of a Electroplating Unit-A case study, " 2011 International Conference on Recent Advancement in Electrical, Electronics and Control Engineers, 25-29, 2011

9. H. Singh, M. Seera, I. Mohamad M.A, "Electrical Energy Audit in a Malaysian University-A Case Study", 2012 IEEE International Conference on Power and Energy, pp. 616-619, 2-5 December 2012.

10. P. Bertoldi, T. Serrenho, "Energy Audits and Energy Management Systems under the Energy Efficiency Directive: what is the current situation?", Proceedings of the EEMODS'15 Conference, September 2015

11. Fleiter Tobias, Gruber Edelgard, Eichhammer Wolfgang, Worrell Ernst, "The German energy audit program for firms- a cost-effective way to improve energy efficiency?", Energy Efficiency, 2012.

12. K. Umesha, Miste. Mieee, "Energy Audit Report on a Technical Institute", IOSR Journal of Electrical and Electronics Engineering (IOSR-JEEE), vol. 4, no. 1, pp. 23-37, Jan. - Feb. 2013.

13. Malik Sameeullah, Jitendra Kumar, Kanhaiya Lal, Jagdish Chander, "Energy Audit: A Case Study of Hostel Building", International Journal of Research in Management Science \& Technology, vol. 2, no. 2, August 2014.

14. S. R. Bhawarkar and S. Y. Kamdi, "Electrical Energy Audit of a Electroplating Unit-A case study, " 2011
International Conference on Recent Advancement in Electrical, Electronics and Control Engineers, 25-29, 2011. 